Vol. 13, pp. 1-21, ISSN: 2072-0394

\title{
Gender Differences In Determinants Of Medical Career Choice
}

\author{
Aamir Hafeez \\ \& \\ Syed Manzoor Hussain Shah \\ Department of Education \\ Hazara University, Mansehra
}

\begin{abstract}
This study aimed to identify the determinants of medical career whether these determinants varied across gender. Drawing from extensive study of existing literature, twenty determinants of medical career were shortlisted. A 60-item purposespecific reliable instrument, designed to assess the comparative influence of determinants, was administered on cross-gender sample of 550 respondents from four public and private medical colleges in Hazara Division of Pakistan. The sample was selected through systematic random sampling, giving gender representation due weight; 293 female students were selected against 253 males. The results showed significant gender-based differences across determinants. The female medical students were found to possess greater social motivation and stronger personality traits than their male counterparts who, with weak personality traits, suffered social and economic compulsions and were only motivated by pecuniary considerations. In the light of findings of the study, it is recommended that due caution be exercised in forming gender-related opinions and sanctifying age-old 'established' views. It is preferable that natural inclinations are nurtured to eventually pave way for a psychologically healthy society comprising individuals seeking success through inner fulfilment than through adjustment to unbending and arbitrary social dictates.
\end{abstract}

Keywords: Gender, Career Choice, Determinants, Medicine, Social and Economic Motivation, Personality Traits.

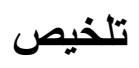

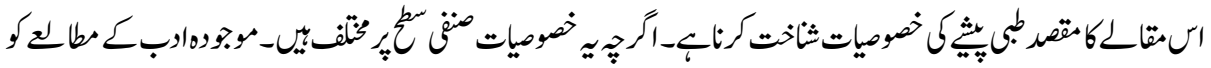

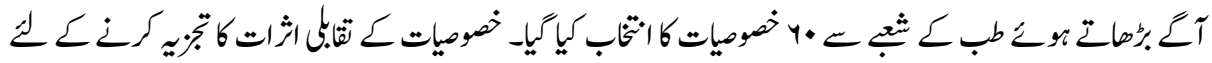

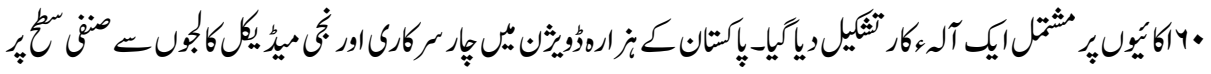

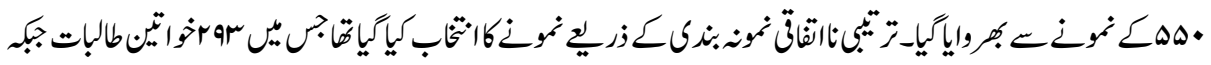

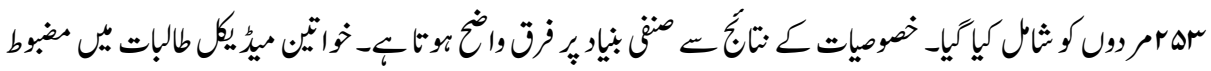

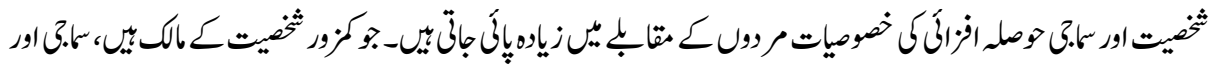

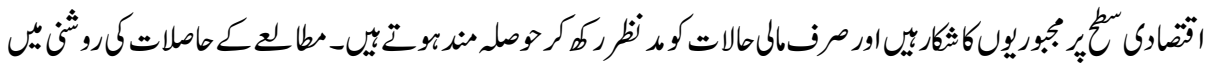

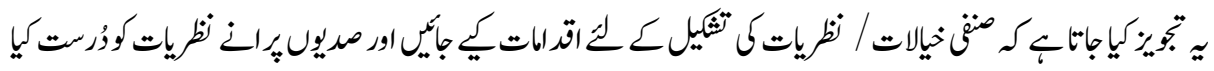




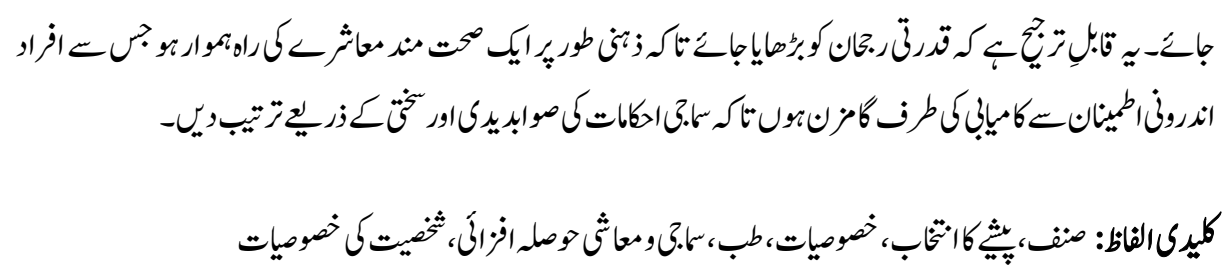

\section{Introduction}

The question of gender continues to provide stimulating substance for research. Despite the worldwide deliberate effort to narrow gender differences through legislative and procedural provisions, the differences continue to somewhat spontaneously surface, thereby demonstrating the resilience of the hardened and long-accepted social and economic norms in a society. The history of gender discrimination is most avowedly interpreted as the history of transformation in the role of women in society. In Pakistan, this transformation in women's role is most palpably observed in the nation's medical colleges. Females make up the largest majority of students studying medicine. For many years, an official embargo kept male students' quota in medical colleges at $80 \%$, leaving $20 \%$ to women. With the scrapping of this condition by the Supreme Court, now an average of $80 \%$ to $85 \%$ students in Pakistan's medical colleges are women (Zikriya, 2014). Men only outnumber women in the medical colleges located in deeply conservative regions of the country, like in some areas of Balochistan and Khyber Pakhtunkhwa. In Punjab and Sindh, however, women overwhelmingly dominate. This could largely be considered as a positive sign for women's prospects in Pakistan. Alternatively, there is a noticeable lack of avenues for women to enter careers that are traditionally available to men alone (Ali et al., 2009)

The confines of a patriarchal society impinge more upon its weaker section (William, 2000). The choices available to men for entering an economically stable and socially respectable vocation in Pakistan are visibly greater than females (Ali et al., 2009). Relatedly, the reasons put up for the larger number of female medical students in medical colleges range from thirst for social status and magnitude of studies involved to males' distractions and attraction of other financially-rewarding occupations. Nevertheless, the consequences of women participation in labour force are irreversible and include the natural corresponding decline in the size of family, female sharing in the overall economic development, improved living standard of family and greater opportunities to harness children's talent (Hyde, 2005). Studies in the field also point to the fact that this relative feminine economic independence also paves way to a steady development of democratic ideals and domestic environment that weakens male influence (Fortin, 2005).

Studies on dynamics of pursuing a career indicate the presence of a number of determinants that exercise their influence in society through wider social perceptions 
about a profession, societal compulsions of one's circumstances, domestic pressures, prestige and reverence of a profession, etc. Economic motivations and pressures dictate a future vocational choice through market competitiveness, instinctive evasion of past deprivations and growth prospects. Then, there are determinants with basis in individual personality traits, whereby a similar situation may elicit a different response from two individuals. The study of gender differences in response to these career motivations and compulsions would reflect on the existing gender-effective social, economic and personality-based conditions in that society.

\section{Literature Review}

Extrinsically, female students in medicine have been shown to obtain greater success in comparison to men (Ferguson et al., 2002). This is also the case with higher education (Kilminster et al., 2007). Woolf (2009) has discovered that men as students are less conscientious than women. One reason for this could be the interpersonal skills, which have shown to be more different between the sexes than within one sex (Cameron, 2009). On the other hand, in the more practical domains, men have been shown to lead the way. A study by Adler (2007) found men to be possessing better leadership traits. Even in the field of academic medicine, Nonnemaker (2000) discovered that while there were more female entrants in the field, their promotion rate was perceptibly lower than that of the males. Also, becoming a successful woman it takes great effort to reach the same status as men (Taylor et al., 2001). Elton (2009) has deduced, due to these consequences, men in medicine earn more than women.

It has been demonstrated that women in medicine suffer greater anxiety than men (Eurydice, 2005) and are less satisfied than their male counterparts (Lepnurm et al, 2006). The career satisfaction of doctors may also be determined by environmental factors. Byars \& McCubbin, (2001) detected that women took to child-related tasks more readily. Moreover, women medical practitioners with children were found less satisfied with their careers as compared to their counterparts with children (Furnham 2005).

The conventional thought in societies maintains that there are inborn differences between sexes and, therefore, they are meant to take up different roles in life (Lapan et al., 2000). Turner et al (2008) found differences between males and females as to their roles and activities in most societies and that males enjoyed greater access to resources and autonomy for career decisions. This approach sees biological and, therefore, permanent differences between the genders. The implication is that men and women are attuned to disparate vocations, i.e. public roles for men because of their being physically stronger with greater mechanical, spatial and numerical abilities; and private role for women, owing to their early maturing, being better at verbal skills and having a better oral and aesthetic perspective (Lubinski \& Benbow, 2006). It follows from this view that education should attempt to mould men and women to their respective roles. 
The progressive approach sees gender roles being crafted under historic, cultural and social influences in the broader patriarchal set ups. Gibbons (2009) found that the transition in society was visible in the change in aspirations of women, irrespective of their being increasingly burdened by keeping jobs despite marriage because of increased economic burden. Hyde (2005) found that both genders possessed similar psychological traits. Education, thus, ought to lessen coercive influences and pave way for equality of sexes (Turner \& Lapan, 2005).

Paechter (2000) asserts that study material in most countries is built on gender specific assumptions and does not address gender equality issues. For instance, it is assumed that men take readily to Maths and Science and women to languages and literature. It has been argued that the narrow choice of subjects limits gender differentiation, while whenever the choice is offered, the boys and girls converge on subjects generally identified with their gender (Eisenhart, 2008). It has been showed that while the use of technology is the same by both genders, boys use technology more for entertainment purposes (Papastergiou \& Solomonidou, 2005). Plant et al. (2009) showed that boys related to Physics better than girls and the aspects of science they were interested in were different. Also, that girls were more interested in counselling, arts and medicine, while the boys were more attracted to Physics and other technical fields. Margolis et al. (2002) states that men were more motivated by Science and Maths and women by biology. Further, among both with scientific mindset, men were more likely take up non-medical careers like engineering, etc, a fact attested by gender demographics in Pakistan's medical colleges. Social and economic necessities also oblige improved academic performance (Cool, 2010), especially when (as in Pakistan) there are larger professional avenues available to males than females.

Lubinski and Benbow (2006) maintained that hidden curriculum impacts social interactions between students and reinforces gender differentiation. Boys have been found to wield greater influence, take greater school space and teacher-time than girls (Myers et al., 2007). Eccles (2006) asserted that patterns of male and female roles established at schools are repeated later in the society itself. Self-concept developed during their school days endures at later stages of students' lives. Boys have been found to display truancy, indifference and disruptiveness (Van de Gaer et al., 2006; Seed, 2006).

Researches point out to both gender-based similarities and differences in vocational aptitudes and inclinations. Greenberger (2002) substantiated that boys are continually propelled towards the traditional masculine vocation, which are economically more rewarding, while there is a constant expectation that girls went into the more traditional areas such as medicine, childcare, nursing, etc. Contrarily, Bourzgui (2012) contended that both men and women have similar ambitions and influences in joining medicine. Roter et al (2002) demonstrated that female doctors have greater interpersonal skills and are able to relate more to a patient than male doctors. A study by Correll and Benard (2005) showed 
that by general perception, men were thought to be better managers than women. Another study showed women applicants for a job who were mothers subjected to greater rigorous assessment than men who were fathers. Goldin and Rouse (2000) found a similar maleoriented conditioning during musical auditioning comprising males and females. Similarly, the results of a study by Sinclair and Kunda (2000) revealed greater negative evaluation of female teachers than that of males. In a glaring finding, Livaditis (2003) stated that successful women were especially disliked for appearing competent. At workplace too, women experience 'invisible' differentiation, with their advice or input ignored or given less value than men's (Ridgeway and Correll, 2004). Relatedly, Lafontaine, \& Monseur (2009) had found that more than $72 \%$ women scientists encountered discriminatory behaviour against them compared to men's $13 \%$.

It has been found motivation to enter medicine differs in men and women, with men valuing working conditions and women value the family, human and welfare factors (Buddeberg-Fischer et al, 2003). Also, women regard compassion and egalitarianism more than men and the urge for power or conformity less than them (Gjerberg, 2002). Reed \& Buddeberg-Fischer (2006) detected that female students preferred working parttime in future. All said, a number of factors combine to dictate career decision. Melhuish et al. (2008) showed the continued impact of attainment of a wide range of family and home-learning factors on career choice.

A cohort of globally-recognized elements seem also to apply to Pakistani medical arena. These combine to reinforce the female fascination for medical profession, such as high social standing of medical profession (Gibis et al., 2012), respectable living standards enjoyed by the medical practitioners (Dorsey et al., 2005), stable future prospects (Good et al., 2003) and monetary satisfaction (Lefevre et al., 2010). Also, the unabated developments in medical profession over the past years have seen the occupational diversity and absorption in the field expand exponentially with the career options extending beyond the stereotypical physicians and surgeons to include such career lines as health administrators, occupational therapists, medical educationists, and clinical researchers (Siddique, 2012). The mushroom growth of private medical colleges in Pakistan over the past decades (from 16 in 1981 to 88 presently) has added another intricate strand to the dynamics that are not extensively researched in the first place (Jafarey, 2009). On the other end of the spectrum exist the compulsions that wean female doctors away from their clinical practice, like the rising demand for a doctor spouse, social inacceptance, rampant anti-feminism and characteristic apathy in Pakistan's patriarchal society (Ali et al., 2009). The above-mentioned developments are certain to drastically change not only the demography and dynamics of the health sector and medical career, but with it the responses of its largest affectees, i.e. women in medicine, both in Pakistan and the world over (Sanfey et al., 2006). 


\section{Research Methodology}

The study was focused on finding out the determinants of medical career among students of medical colleges in Hazara region. This exploratory research employed one-shot crosssectional survey as data gathering instrument. Among other objectives, it sought to find gender-based differences in comparative influence of career determinants within the social, economic and personality domains.

Participants: The population for the study comprised MBBS students of four public and private colleges in Hazara region $[\mathrm{n}=2750]$. With the majority from upper-middle and lower-middle class, they aged between 18 to 25 years and belonged to all stages/years of MBBS. The sample of the study was derived through systematic random sampling technique. The proportional representation of the institutions and gender was ensured (53\% females to $47 \%$ males). The appreciable representation from both public and private medical colleges made the findings broadly applicable to both categories of medical students ( $45.5 \%$ public to $54.5 \%$ private). $54 \%$ of sample came from urban areas, while about $24 \%$ and $22 \%$ belonged to suburban and rural areas respectively.

Table: 1

Sample size and gender-wise classification

\begin{tabular}{|c|c|c|c|c|c|c|}
\hline \multirow[b]{2}{*}{ College } & \multirow[b]{2}{*}{$\mathbf{N}$} & \multirow[b]{2}{*}{$\begin{array}{c}\text { Sample } \\
(20 \%)\end{array}$} & \multicolumn{2}{|c|}{ Enrolled Males } & \multicolumn{2}{|c|}{ Enrolled Females } \\
\hline & & & Total & $20 \%$ & Total & $\begin{array}{l}20 \\
\%\end{array}$ \\
\hline Ayub Medical College & 1250 & 250 & $812(65 \%)$ & 162 & $438(35 \%)$ & 88 \\
\hline $\begin{array}{l}\text { Abbottabad International } \\
\text { Medical College }\end{array}$ & 500 & 100 & $125(25 \%)$ & 25 & $375(75 \%)$ & 75 \\
\hline Frontier Medical College & 500 & 100 & $310(62 \%)$ & 62 & $190(38 \%)$ & 38 \\
\hline Women Medical College & 500 & 100 & - & - & $500(100 \%)$ & 100 \\
\hline Total & 2750 & 550 & $1247(45 \%)$ & 249 & $1503(55 \%)$ & 301 \\
\hline
\end{tabular}

Scale Development and Pilot Study: Extensive review of literature yielded twenty broad determinants representing the most significant motivations and compulsions for entering a career in medicine. These wielded their respective influence under the wider domains, viz. social motivation, social compulsion, economic motivation, economic compulsion, strong personality traits and weak personality traits. A reliable instrument, framed to meet the specific requirement of study with due consideration for Pakistani ethos, was developed to measure the respective impact or influence of career determinants. This 'Impact profiler' represented determinants through three manifestations each, making it a self-report inventory of 60 multiple-choice questions based on Likert Scale. A 5-tier sociability construct was developed against which the students' aggregate impact scores were to be compared to gauge the influence of given determinants and domains. The instrument was treated to a pilot study upon mix-gender group of 40 students from the medical colleges, considering the similarity of students to the ones in the actual sample. 
The pilot testing results gave a good reliability figure of 0.965 on Cronbach Alpha testing, thus validating the instrument as reliable through test-retest procedure and valid through internal consistency method. Personal data including the students' family background, SES, area of origin etc were gathered through a 'Personal Data Form' administered along with the instrument.

Data Analysis: Statistical Package for the Social Sciences (SPSS version 17.0) was used for data analysis. Data were analyzed through descriptive statistics including means and standard deviation. Mean scores received from results when compared against the construct gave the relative strength of determinants and domains. t-test was used to generate results bearing highly instructive differences on the basis of gender. Results were worked out both in relation to 20 earmarked determinants as well as the 6 domains of social motivation and social compulsion, economic motivation and economic compulsion, and strong personality traits and weak personality traits.

Table: 2

Difference between influence of domains on male and female medical students $(\mathrm{N}=550)$

\begin{tabular}{|c|c|c|c|c|}
\hline Domain & Gender & Mean & Std. Deviation & $\mathbf{T}$ \\
\hline \multirow[t]{2}{*}{ Social Motivation } & Male & 30.28 & 6.74 & \multirow[t]{2}{*}{$-3.37 * *$} \\
\hline & Female & 32.16 & 6.38 & \\
\hline \multirow[t]{2}{*}{ Social Compulsion } & Male & 14.58 & 5.10 & \multirow[t]{2}{*}{$2.96 *$} \\
\hline & Female & 13.35 & 4.67 & \\
\hline \multirow[t]{2}{*}{ Economic Motivation } & Male & 15.50 & 5.42 & \multirow[t]{2}{*}{$2.87 *$} \\
\hline & Female & 14.19 & 5.24 & \\
\hline \multirow[t]{2}{*}{ Economic Compulsion } & Male & 21.42 & 8.36 & \multirow[t]{2}{*}{$3.91 * *$} \\
\hline & Female & 18.78 & 7.47 & \\
\hline \multirow[t]{2}{*}{ Strong Personality Traits } & Male & 48.60 & 12.97 & \multirow[t]{2}{*}{$-5.25^{* *}$} \\
\hline & Female & 54.00 & 11.18 & \\
\hline \multirow[t]{2}{*}{ Weak Personality Traits } & Male & 34.07 & 13.65 & \multirow[t]{2}{*}{$4.83 * *$} \\
\hline & Female & 28.97 & 11.07 & \\
\hline
\end{tabular}

$*=p<0.05, * *=p<0.01$

Table-. 2 informs that $\mathrm{t}=3.37(\mathrm{p}<0.05)$ for social motivation; $\mathrm{t}=2.96(\mathrm{p}<0.05)$ for social compulsion; $\mathrm{t}=2.87(\mathrm{p}<0.05)$ for economic motivation; $\mathrm{t}=3.91 \quad(\mathrm{p}<0.05)$ for economic compulsion; $\mathrm{t}=3.5 .25(\mathrm{p}<0.05)$ for strong personality traits; $\mathrm{t}=4.83(\mathrm{p}<0.05)$ for weak personality traits. Hence, there is significant difference between male and female students with regard to the influence of all six domains. Further, the values of $t$ indicate that male students are more influenced than females by social and economic compulsions, though they also carry significantly greater economic motivation than the females. Their personalities are more constrained as to choice of medicine than females. The results also show that female students are socially more motivated, carry personalities with significantly greater positive tendencies and motivation than males. 
Table: 3

Difference between influence of career determinants on male and female medical students $(\mathbf{N}=\mathbf{5 5 0})$

\begin{tabular}{|c|c|c|c|c|}
\hline Determinant & Gender & Mean & Std. Deviation & $\mathbf{T}$ \\
\hline \multirow[t]{2}{*}{ Nobility and reverence of profession } & Male & 12.11 & 2.59 & \multirow[t]{2}{*}{$-3.93 *$} \\
\hline & Female & 12.86 & 1.84 & \\
\hline \multirow[t]{2}{*}{ Reassuring social perceptions } & Male & 9.49 & 2.88 & \multirow[t]{2}{*}{$-2.94 * *$} \\
\hline & Female & 10.22 & 2.90 & \\
\hline \multirow[t]{2}{*}{ Social status \& prestige } & Male & 8.67 & 3.33 & \multirow[t]{2}{*}{-1.47} \\
\hline & Female & 9.09 & 3.36 & \\
\hline \multirow[t]{2}{*}{ Domestic \& Familial Pressures } & Male & 7.61 & 2.97 & \multirow[t]{2}{*}{$2.60 *$} \\
\hline & Female & 6.97 & 2.81 & \\
\hline \multirow[t]{2}{*}{ Broader societal compulsions } & Male & 6.97 & 3.19 & \multirow[t]{2}{*}{ 2.36* } \\
\hline & Female & 6.38 & 2.67 & \\
\hline \multirow[t]{2}{*}{ Future growth prospects } & Male & 8.14 & 3.15 & \multirow[t]{2}{*}{1.46} \\
\hline & Female & 7.73 & 3.31 & \\
\hline \multirow[t]{2}{*}{ Emulating prosperous examples } & Male & 7.37 & 3.03 & \multirow[t]{2}{*}{$3.68 * *$} \\
\hline & Female & 6.46 & 2.73 & \\
\hline \multirow[t]{2}{*}{ Overcoming past deprivations } & Male & 7.32 & 3.32 & \multirow[t]{2}{*}{$3.43 * *$} \\
\hline & Female & 6.37 & 3.14 & \\
\hline \multirow[t]{2}{*}{ Job market competitiveness } & Male & 7.67 & 3.34 & \multirow[t]{2}{*}{ 2.35* } \\
\hline & Female & 7.02 & 3.17 & \\
\hline \multirow[t]{2}{*}{ Future Economic Uncertainties } & Male & 6.43 & 3.18 & \multirow[t]{2}{*}{$4.08 * *$} \\
\hline & Female & 5.39 & 2.80 & \\
\hline \multirow[t]{2}{*}{ Personal drive and determination } & Male & 9.97 & 3.21 & \multirow[t]{2}{*}{$-3.80 * *$} \\
\hline & Female & 11.00 & 3.12 & \\
\hline \multirow[t]{2}{*}{ Ambition and aspiration } & Male & 9.95 & 3.88 & \multirow[t]{2}{*}{$-5.27 * *$} \\
\hline & Female & 11.60 & 3.48 & \\
\hline \multirow[t]{2}{*}{ Talent and aptitude for medicine } & Male & 8.71 & 3.44 & \multirow[t]{2}{*}{$-3.84 * *$} \\
\hline & Female & 9.81 & 3.23 & \\
\hline Initiative and resourcefulness & Male & 8.84 & 2.98 & -1.69 \\
\hline & Female & 9.25 & 2.80 & \\
\hline Altruism and compassion & Male & 11.13 & 3.45 & $-4.54 * *$ \\
\hline & Female & 12.34 & 2.78 & \\
\hline Gullibility \& Lassitude & Male & 6.67 & 2.95 & 0.98 \\
\hline & Female & 6.43 & 2.86 & \\
\hline Myopic and disorganized & Male & 7.51 & 3.78 & $4.54 * *$ \\
\hline & Female & 6.12 & 3.39 & \\
\hline Indecisiveness and reluctance & Male & 6.52 & 3.48 & $5.19 * *$ \\
\hline & Female & 5.15 & 2.70 & \\
\hline Diffidence and reserve & Male & 6.63 & 3.50 & $4.82 * *$ \\
\hline & Female & 5.30 & 2.93 & \\
\hline Yielding despite different aptitude & Male & 6.74 & 3.30 & $2.78 * *$ \\
\hline & Female & 5.97 & 3.19 & \\
\hline
\end{tabular}

$*=p<0.05, * *=p<0.01$ 
Table-3 indicates that $\mathrm{t}=3.93(\mathrm{p}<0.05)$ for nobility and reverence of profession; $\mathrm{t}=2.94$ $(\mathrm{p}<0.05)$ for reassuring social perceptions; $\mathrm{t}=2.60(\mathrm{p}<0.05)$ for domestic and familial pressures; $t=2.36(p<0.05)$ for broader societal compulsions; $t=3.68(p<0.05)$ for emulating prosperous examples; $t=3.43(p<0.05)$ for overcoming past deprivations; $t=2.35(p<0.05)$ for job market competitiveness; $t=4.08(p<0.05)$ for future economic uncertainties; $t=3.80$ $(\mathrm{p}<0.05)$ for personal drive and determination; $\mathrm{t}=5.27(\mathrm{p}<0.05)$ for ambition and aspiration; $\mathrm{t}=3.87(\mathrm{p}<0.05)$ for talent and aptitude for medicine; $\mathrm{t}=4.54(\mathrm{p}<0.05)$ for altruism and compassion; $t=4.54 \quad(p<0.05)$ for myopic and disorganized; $t=5.19 \quad(p<0.05)$ for indecisiveness and reluctance; $\mathrm{t}=4.82(\mathrm{p}<0.05)$ for diffidence and reserve; and $\mathrm{t}=2.78$ $(\mathrm{p}<0.05)$ for yielding despite different aptitude. Hence, there is significant difference between male and female students on these aspects. Further, the t values indicate that males are more influenced by domestic pressures and broader societal compulsions. They hold a significantly greater urge to overcome past deprivations and are more conscious about job market competiveness and grappling future economic uncertainties. They are also more primed to emulating prosperous examples. The results show that males are more myopic and disorganized; they lack decision-making, are more diffident and reserved, and yield more pressure for joining medicine despite different aptitude. The results show that female students are more influenced by nobility and reverence of medical profession and reassuring social perceptions about it. They also carry significantly greater personal drive and determination, ambition and aspiration, talent and aptitude for medicine, and altruistic tendencies than their male counterparts. There is no significant difference between male and female students with respect to the influence exerted by social status and prestige; initiative and resourcefulness; and gullibility and lassitude.

\section{Findings}

On the basis of t-test, significant difference between genders was found in all six domains. At 0.01 level, significant difference between male and female students was found in the domains of social motivation, economic compulsion, strong personality traits and weak personality traits. At 0.05 level, significant difference between male and female students was found in the domains of social compulsion and economic motivation. The results reflect greater influence of social and economic compulsions on males, though they also carry greater economic motivation than the females. Their personalities are also more constrained with respect to choice of medical career than the females. On the contrary, the female students are socially more motivated and carry personalities that hold greater positive tendencies and motivation than males.

As regards the career determinants, significant difference between genders was found in 16 out of 20 career determinants. At 0.01 level, significant difference between male and female students was found in the determinants of nobility and reverence of profession; reassuring social perceptions; domestic and familial pressures; emulating prosperous examples; overcoming past deprivations; future economic uncertainties; personal drive and determination; ambition and aspiration; talent and aptitude for medicine; altruism and 
compassion; being myopic and disorganized; indecisiveness and reluctance; diffidence and reserve; and yielding despite different aptitude. At 0.05 level, a significant difference between male and female students was found in the determinants of broader societal compulsions, and job market competiveness.

The results reflected that male students are more influenced than females by domestic pressures and broader societal compulsions. They hold a greater urge to overcome past deprivations and are more conscious than females about job market competiveness and grappling future economic uncertainties. They are also more primed to seizing future growth prospects and emulating prosperous examples. The results show that their personalities are more affected by being myopic and disorganized, and betray greater lack of decision-making, diffidence and reserve, and yielding to pressure for joining medicine despite different aptitude than their female counterparts.

The results also established that female students are more influenced than males by nobility and reverence of medical profession and reassuring social perceptions about it. They also carry greater personal drive and determination; ambition and aspiration; talent and aptitude for medicine; and altruistic tendencies than their male counterparts.

\section{Conclusions and Discussion}

The present study found differences between males and females on a number of determinants, including nobility and reverence of profession; altruism and compassion; ambition and aspiration; personal drive and determination; reassuring social perceptions; talent and aptitude for medicine; job market competiveness; domestic and familial pressures; emulating prosperous examples; overcoming past deprivations; being myopic and disorganized; broader societal compulsions; yielding despite different aptitude; diffidence and reserve; future economic uncertainties; and lack of decision-making. This went counter to McNay's (2000) contention that both men and women had similar ambitions to joining medicine and the factors influencing their decisions are also generally the same.

Female students were found to possess greater motivation based on social factors. This manifests ambition and aspiration of women in Pakistani conservative setting. It also reflected the desire to make their mark through higher social status and prestige accorded to the working women in a predominantly patriarchal society where males and females are expected to fill their separate roles in society (Saad et al, 2011) and where men have power over women (Kao et al, 2000). Moreover, the increased density of female medical students in Pakistan is negatively counter-balanced by lack of alternative career opportunities for females (Abbasi \& Sarwat, 2014). It has been substantiated that boys choose economically-rewarding vocations, while girls are expected to enter into traditional areas such as medicine, childcare and nursing (Greenberger, 2002). However, 
the change in perspective on women has led to 'gender mainstreaming' and during 1990s the thinking about women's conventional roles changed dramatically (Redman, 2009). In the contemporary developed societies of Europe, emerging education reform altogether ignores gender as an issue (Magno \& Silova, 2007). The relative feminine economic independence paves way to democratic ideals and domestic ethos that reduce male influence and authority (Fortin, 2005).

The study found that female students hold the nobility of medicine in greater regard than males. This echoed Booth and Bennett's (2002) finding that males were more affected by prestige than by nobility of the medical vocation. Allied to nobility and humanity in Pakistani society are the religious elements of piety and success in afterlife. Medical ethics in Pakistan is dominated by religious overtones and religion holds a central position in health-related issues (Hyder \& Nadeem, 2001). The findings affirmed that female students were more influenced by reassuring social perceptions about medical profession. Since a number of social perceptions become effective through domestic environment, Riska's (2010) assertion that female students make career decisions relying more on familial advice stood verified. Better chances of matrimonial life and opportunity to have a better spouse could be other strong stimuli for entry into medicine (Zikria, 2014).

The study showed that social compulsions and domestic pressures impacted males more than females. By implication, this observation ran counter to studies that maintained women to bear greater difficulty in balancing work and family responsibilities (Mason et al., 2009) or that female spouses were more affected by family responsibilities than men (Stack, 2004). In the context of emerging Pakistani social perceptions, particularly that of Hazara region, the study did not support the assertion by Drinkwater et al (2008) that female students more readily compromised career aspirations for family life and domestic compulsions or that family traditions exerted greater pressure on women than on men. It may be apt to quote Kinser's (2004) observation here who maintained that political, cultural and economic circumstances are exclusive to every era.

The study did, however, concur with the opinion of Marks and Houston (2002) that women restricted themselves to professions in there exist a precedent of their feminine predecessors fulfilling both domestic and vocational requirements (such as teaching and medicine in our case). This has evidently much to do with the economic openings and societal sanctions, rather than observing domestic duties, as Xie and Shauman (2003) observed that women the world over enjoyed less access to opportunities, resources and independent decision-making. On the general influence of family, relatives and domestic environment, Chak-Keung \& Jing (2010) had revealed that attitudes of close family relatives towards occupations significantly affect the career choice. Saad et al (2011) had stated that nearly $90 \%$ Pakistani medical students joined medicine as a result of familial influence. 
The study revealed that males in their conventionally accepted role bore social compulsions more. Broader societal compulsions impacted individuals by converting larger social perceptions and pressures into individual ambitions. The more an individual interacted with his society, the more he imitated others. It follows, therefore, that men (ostensibly more susceptible to vocational pressures) suffered greater societal compulsions. At societal level, social perceptions about medical profession gave rise to compulsion to imitate and found a potent expression through domestic pressures. These broader societal compulsions are invariably linked to economic issues. The financial prospects, stability of the job and opportunity to improve conditions are compelling elements dictating entry into medicine (Sikandar et al, 2013). Hence, the widely-accepted stability of medical career becomes a constraint and prevents exploring of other fields.

Simard et al's (2008) finding that the future direction of medical students is predominantly guided by monetary considerations was supported by the study. Maguira (2007) had confirmed that doctors the world over enjoy respectable living standards, stable future prospects and monetary satisfaction. However, the exclusivity of material goals impacts the nobility and prestige of the profession (Sikandar et al., 2013). The symptoms of these are the aversion to serve for low salaries in the public sector and the repeatedly substantiated aim of moving abroad (Mushtaq, 2013). Two decades ago, Hasan (1995) had warned about the economically transitioning of medical practice and underscored "the pressures of making two ends meet in an environment of enormous inflation and unreasonable basic expenditure on self and family sustenance".

Men were shown in the study to bear greater economic compulsions and correspondingly stronger economic motivation than women, presumably owing to imposition of their traditional role and constant refrain of fulfilling domestic responsibilities. Male students felt more the brunt of market competitiveness. The claim by Johansson (2007) that men are more interested in financial standing and particularly prone to economic motivation when subjected to social pressures in a conservative setting was borne by the findings of the study. Sanfey (2006) substantiated the primacy of monetary-based lifestyle expectations, career progression, remuneration and prestige among men and of patient care and balanced life among women in medicine (Buddeberg-Fischer et al, 2003). Thus, apart from the fact of universally persisting gender-based wage gaps (Drolet, 2011), the study did not support Baker's (2010)the assertion that both genders accorded similar importance to salary or that females chose career pattern based on economic motivations.

The study also confirmed the imitational value of nurturing ambition. Males showed themselves to be more influenced by successful examples, thus verifying Tyler et al's (2009) claim that inspiring examples and respected specialists attract students towards medicine.

The study found that female students possessed greater strong personality traits than males. This reinforced the view that gender-based identity is shaped by social and historic forces 
(Weeks, 2000). It also alluded to women's greater intrinsic motivation, which is necessary for a career in medicine (Kusurkar, 2011). Women have been shown to display greater determination to overcome hardship, act independently and persevere towards success, in spite of social embargoes (Dweck, 2008). This personal determination could be the result of independent nature of medical vocation, which is one of the biggest incentives (Rogers et al, 2010). The study also found the women to possess greater ambition and aspirations. A number of studies have departed from the conventional approach and established that women are as much ambitious as men (Good et al., 2003; Grant \& Dweck, 2003; Dweck, 2006). The personal aspiration to enter medicine is sown early in childhood, more often by the parents (Stratton et al, 2005). The domestic culture also mentally conditions students to venture into one kind of vocation (Barbour \& Gray, 2011). Women and men have been shown to have similar IQ (Haier et al., 2005) and the gender differences in cognitive abilities have been proved to be inconsequential (William, 2000).

The findings also established women to have greater intrinsic aptitude for medicine, as has been discovered in the case of Pakistani students (Akhund, 2010). Academic achievement and studiousness are predictors of entry into medicine (Saad et al, 2011). The study found women to have greater intrinsic interest in the medical field. This reinforces the assertion that girls are less interested in maths, computer science, engineering, or physical sciences and more inclined towards life sciences, social sciences and humanities (Jacobs, 2006).

Altruism and compassion were found to be a very strong sentiment among the medical students, and thus an influential determinant of medical career choice. A number of researches have established that most medical practitioners derive motivation and satisfaction from human values (Dugan et al., 2005). Female students were found to have greater spirit of altruism, compassion and egalitarianism than men, a finding affirmed by earlier studies (Bickel, 2001; McNay, 2000; Redman et al, 2004). Women have been found to be more welfare-oriented and less conforming or power-hungry than men (Konrad et al., 2000).

\section{References}

Abbasi, M. N. \& Sarwat, N. (2014). Factors Inducing Career Choice: Comparative Study of Five Leading Professions in Pakistan. Pakistan Journal of Commerce and Social Sciences, vol.8:3, pp.830-845.

Adler, D.G., Hilden, K., Wills, J.C., Quinney, E. \& Fang, J.C. (20070). What Drives US Gastroenterology Fellows to Pursue Academic vs. Non Academic Careers? Results of a National Survey. Am J Gastroenterol, vol.105:6, pp.1220-3. 
Akhund, S., Shaikh, Z. A. \& Kolachi, H. B. (2010). Career Related Choices of Medical Students from an International Medical College of Karachi, Pakistan. Karachi: Dow Medical College Press.

Ali, M. S., Suliman, M. I., Kareem, A. \& Iqbal, M. (2009). Comparison of Gender Performance on an Intelligence Test among Medical Student, Mirpur: Mohi-udDin Islamic Medical College Press.

Baker, M. \& Drolet, M. (2010). A New View of the Male/Female Pay Gap,' Canadian Public Policy, vol.XXXVI:4, pp.428-464.

Barbour, A. \& Gray, (2008) Medical Student Attitudes towards Financial Incentives in Healthcare Settings, Washington: George Washington University.

Booth, C. \& Bennett, C. (2002). Gender Mainstreaming in the European Union: Towards a New Conception and Practice of Equal Opportunities? The European Journal of Women's Studies, vol.9:4, pp.430-446.

Bourzgui, F., Abidine, Z., Serhier, Z., Diouny, S. \& Othmani, M. B. (2012). Motivational Factors Influencing Career Choices of Moroccan Dental Students. El Jadida: Chouaib Doukkali University Press.

Buddeberg-Fischer, B., Dietz, C., Klaghofer, R. \& Buddeberg, C. (2006). Swiss Residents' Arguments for and Against a Career in Medicine, British Medical Health Services Research, vol.6:98.

Buddeberg-Fischera, B., Klaghofera, R., Abelb, T. \& Buddeberg, C.a (2003). The Influence of Gender and Personality Traits on the Career Planning of Swiss Medical Students. Swiss Medical Weekly, vol.133:2, pp.535-540.

Byars, A. M. \& McCubbin, L. D. (2001). Trends in Career Development Research with Racial/Ethnic Minorities: Prospects and Challenges (in G. Ponterotto, I. M. Casas, L. A. Suzuki, \& C. A. Alexander Eds. Handbook of Multicultural Counselling $\left\{2^{\text {nd }}\right.$ ed., pp. 633-654). Thousand Oaks, CA: Sage.

Cameron, D. A. (2009). Language in Common. The Psychologist, vol.22:7.

Chank-Keung, S. W. \& Jing, G. L. (2010). Will Parental Influences affect Career Choice? International Journal of Hospitality Management, vol.22:1, pp.82-102. 
Cool, J. (2010) Wage Gap Between Women and Men. Ottawa: Library of Parliament, Publication no. 2010-30-E.

Correll, S. J. (2001). Gender and the Career Choice Process: The Role of Biased SelfAssessments, American Journal of Sociology, vol.106:6, pp.1691-1730.

Dorsey, E. R., Jarjoura, D. \& Rutecki, G. W. (2005). The Influence of Controllable Lifestyle and Sex on the Specialty Choices of Graduating U.S. Medical Students, 1996-2003, Academic Medicine, vol.80:1, pp.791-796.

Drinkwater, J. (2008). The Effect of Gender on Medical Students'Aspirations: A Qualitative Study, Medical Education, vol.42:1, pp.420-426.

Drolet (2011). Why Has the Gender Wage Gap Narrowed? London : Penguin

Dugan. E., Trachtenberg, F. \& Hall, M. A. (2005). Development of Abbreviated Measures to Assess Patient Trust in a Physician, a Health Insurer, and the Medical Profession, Biomedical Central journal of Health Services and Research, vol.5:66, pp.55-64.

Dweck, C. S. (2008). Clarifying Achievement Goals and Their Impact, Journal of Personality and Social Psychology, vol.85:3, pp.541-53.

Eccles (2006). Where are all the Women? Gender Differences in Participation in Physical Science and Engineering. In S. J. Ceci \& W. M. Williams (eds.), why aren't more Women in Science? Top Researchers Debate the Evidence Washington, DC: American Psychological Association, pp.199-210.

Eisenhart, M. (2008). We Can't Get there from here: High School Girls Consider Engineering. Presentation for a Women in Engineering ProActive Network (WEPAN) National Webcast.

Elton, M. A. (2009). Women and Medicine: The future. London: Royal College of Physicians.

Eurydice. (2005) How Boys and Girls in Europe are Finding their Way with Information and Communication Technology. Brussels: Eurydice.

Ferguson E, James D, Madeley L. (2002). Factors Associated with Success in Medical School: Systematic Review of the Literature, British Medical Journal, vol.324:2, pp.952-7. 
Fortin, N. (2005) Gender Role Attitudes and the Labour Market Outcomes of Women Across OECD Countries, Oxford Review of Economic Policy, vol.21:3, pp. 416-38.

Furnham, A. (2008). The Psychology of Behaviour at Work: The Individual and the Organization. Hove: Psychology Press.

Gibbons, M. T. (2009). Engineering by the Numbers in Profiles of Engineering and Engineering Technology Colleges, Washington, DC: American Society for Engineering Education.

Gibis, B., Heinz, A., Jacob, R. \& Müller, Ch. (2012). The Career Expectations of Medical Students. Dtsch Arztebl Int. Vol. 109, Issue. 18, 327-332. Girls in Physics Lessons. [Online] Available at: http://lise.univie.ac.at/artikel/ hoffmann.htm

Gjerberg, E. (2002) Gender Similarities in Doctors' Preferences-and Gender Differences in Final Specialisation, Soc Sci Med. vol.54:5, pp.591-605.

Goldin C. \& C. Rouse (2004) Orchestrating Impartiality: The Impact of "Blind" Auditions on Female Musicians, American Economics Review, vol.90:3, pp.715-740.

Good, C., Aronson, J. \& Inzlicht, M. (2003). Improving Adolescents' Standardized Test Performance: An Intervention to Reduce the Effects of Stereotype Threat, Applied Developmental Psychology, vol.24:3, pp.645-62.

Greenberger, M. (2002). Nation's High Schools still Operate "Separate and Unequal" Vocational Education for Male and Female Students, retrieved June 12, 2002, from: http://www.nwlc.org/details.cfm?id=1135\&section=education

Haier, R. J., Jung, R. E., Yeo, R.A., Head, K. \& Alkire, M. T. (2005) Theneuroanatomy of General Intelligence: Sex Matters. NeuroImage. Vol.25, Issue.3. :320-7.

Hasan, M. (1995). Medical Ethics - Past and Present, Pakistan Heart Journal, vol. 28:1, pp.63-72.

Hyde, J.S. (2005) The Gender Similarities Hypothesis, American Psychologist, vol. 60:6, pp.581- 592.

Hyder, A. A. \& Nadeem, S. (2001). Review of Ethics Discourse in Pakistan, Health, Population and Nutrition Journal, vol.2:1, pp.23-45. 
Jacobs, J. E., Chhin, C. S. \& Bleeker, M. M. (2006). Enduring Links: Parents' Expectations and their Young Adult Children's Gender-Typed Occupational Choices, Educational Research \& Evaluation, vol.12:4, pp.395-407.

Jafarey, N. A. (2009). The Final M.B.B.S. (Certifying) Examination. J. Pak. Med. Assoc., 2009. vol.34:1, pp.54-36.

Johansson, E. E. (2007). From Calling to a Scheduled Vocation: Swedish Male and Female Students' Reflections on Being a Doctor, Medical Teaching, vol.29:1, pp.37-55.

Kao, M.Y., Lu, P.H., Li, M.P., et al. (2000). Medical Students' Specialty Preferences and Exploration of Relevant Factors, Medical Education, vol.4:1, pp.23-37.

Kilminster, S., Downes, J., Gough, B., Murdoch-Eaton, D. \& Roberts, T. (2007). Women in Medicine - Is there a Problem? A Literature Review of the Changing Gender Composition, Structures and Occupational Cultures in Medicine, Medical Education, vol.41:1, pp.39-49.

Kinser, A. E. (2004). Negotiating Spaces for Third-wave Feminism, NWSA Journal, vol.16:3, pp.124-153.

Konrad, A. M., Ritchie, J. E., Jr., Lieb, P. \& Corrigall, E. (2000). Sex Differences and Similarities in Job Attribute Preferences: A Meta-analysis. Psychological Bulletin, vol.126:4, pp.593-641.

Kruegar, (2002). Teaching and Learning in Medicine: An International Journal Publication, Journal of Pakistan Medical Association, vol.53:7, pp.213-234.

Kusurkar, R. A., Tencate, T. H.J., Vanasperen, M. \& Croiset, G. (2011). Motivation as an Independent and a Dependent Variable in Medical Education: A Review of the Literature. Utrecht: University Medical Center.

Lafontaine, D. \& Monseur, C. (2009). Gender Gap in Comparative Studies of Reading Comprehension: To What Extent do the Test Characteristics make a Difference? European Educational Research Journal, vol.8:1, pp.69-79.

Lapan, R. T., Adams, A., Turner, S., \& Hinkelman, J. (2000). Seventh graders' vocational interest and efficacy expectation patterns. Journal of Career Development, vol.26:3, pp.215-229. 
Lefevre, J. H., Roupret, M., Kerneis, S. \& Karila, L. (2010) Career Choice of Medical Students: A National Survey of 1780 Students, Medical Edcuation, vol.44:1, pp.603-612.

Lepnurm, R., Dobson, R., Backman, A. \& Keegan, D. (2006) Factors Explaining Career Satisfaction among Psychiatrists and Surgeons in Canada, Canadian Journal of Psychiatry, vol.51:2, pp.243-55.

Livaditis, M., Zaphiriadis, K., Samakouri, M., Tellidou, C. Tzavaras, N. \& Xenitidis, K. (2003). Gender Differences, Family and Psychological Factors Affecting School Performance in Greek Secondary School Students, Educational Psychology, vol.23:2, pp.223-231.

Lubinski, D. \& Benbow, P. (2006) Study of Mathematically Precocious Youth After 35 Years, Perspectives on Psychological Science, vol.1:3, pp.316-345.

Magno, C. \& Silova, I. (2007). Teaching in Transition; Examining School-Based Inequities in Central / South-Eastern Europe and the Former Soviet Union, International Journal of Educational Development, vol.27:3, pp.647-660.

Maguire, M., (2007). Home-school Relations. In K. Myers, H. Taylor, S. Adler \& D. Leonard, eds. Gender watch ...still watching. Stoke-On-Trent: Trentham, pp. 62-64.

Margolis, J. \& Fisher, A. (2002). Unlocking the Clubhouse: Women in computing. Cambridge: Massachusetts Institute of Technology.

Marks, G. \& Houston, D. M. (2002). The Determinants of Young Women's Intentions About Education, Career Development and Family Life, Journal of Education and Work, vol.15:3, pp.321- 336.

Mason, M. A., Goulden, M. \& Frasch, K. (2009). Why Graduate Students Reject the Fast Track. Academe Online, vol.95:1, pp.34-55.

McNay, L. (2000). Gender and Agency: Reconfiguring the Subject in Feminist and Social Theory. Cambridge: Polity Press.

Melhuish, E., Phan, M.B., Sylva, K., Sammons, P., Siraj-Blatchford, I. \& Taggart, B., (2008). Effects of the Home Learning Environment and Preschool Center Experience Upon Literacy and Numeracy Development in Early Primary School, Journal of Social Issues, vol.64:1, pp.95-114. 
Mushtaq, U. (2013). Career Preferences and Research Attitude among Pakistani Medical Students, Journal of Health Sciences, Punjab University, vol.30:10, pp.17-87.

Myers, K., Taylor, H., Adler, S. \& Leonard, D. (2007). Gender Watch: Still Watching. Stoke-On-Trent: Trentham.

Nonnemaker, L. (2000). Women Physicians in Academic Medicine - New Insights from Cohort Studies, New England Journal of Medicine, vol.342:3, pp.399-405.

Paechter, C. (2000). Changing School Subjects: Power, Gender and the Curriculum. Buckingham: Open University Press.

Papastergiou, M. \& Solomonidou, C. (2005). Gender Issues in Internet use and Favourite Internet Activities among Greek High School Pupils Inside and Outside Schools, Computers and Education, vol.44:4, pp.377-393.

Plant, E. A., Baylor, A. L., Doerr, C. E. \& Rosenberg-Kima, R. B. (2009). Changing Middleschool Students' Attitudes and Performance Regarding Engineering with Computer-based Social Models, Computers and Education, vol.53:2, pp.209-15.

Redman, D. S., Straton, B. J. \& Young, C. (2009). Determinants of Career Choices among Women and Men Medical Students and Interns. Medical Education 2009; vol.28, pp.361-71.

Ridgeway, A. Shelley J. C. (2004). Unpacking the Gender System: A Theoretical Perspective on Gender Beliefs and Social Relations. Gender \& Society, vol.15:1, pp.510-531.

Riska E. (2011). Gender \& Medical Careers, Maturitas Journal, vol.68:2, pp.264-267.

Rogers, M. E., Creed, P. A., Searle, J. \& Hartung, P. J. (2010). The Physician Values in Practice Scale-Short Form: Development and Initial Validation. Journal of Career Development. doi: 10.1177/0894845310363593.

Roter, D. L., Hall, J. A. \& Acki, Y. (2002). Physician Gender Effects in Medical Communication: A Meta-analytic Review, The Journal of the American Medical Association, vol.288:2, pp.756-764.

Saad, S. M. A., Fatima, S. S. \& Faruqi, A. A. (2011) Students Views Regarding Selecting Medicine as a Profession. Karachi: Dow Medical College Press. 
Sanfey, H. A., Saalwachter-Schulman, A. R., Nyhof-Young, J. M., Eidelson, B. \& Mann, B. D. (2006). Influences on Medical Students Career Choice. Archives of Surgery, vol.141:3, pp.1086-1094.

Siddiqui, Z. S. (2012). The Changing Face of Medical Education: Implications for Pakistan. Brisbane : University of Western Australia.

Sikandar, R., Bashir, N., Nisar, N. \& Khawaja, R. A. (2013). Students' Attitude and Motivation towards Medical Career Prior to entering Professional Practice. Karachi: Journal of Liaquat University of Medical \& Health Sciences.

Simard, C., Henderson, A. D., Gilmartin, S. K., Schiebinger, L. \& Whitney, T. (2008). Climbing the Technical Ladder: Obstacles and Solutions for Mid-Level Women in Technology. Stanford, CA: Michelle R. Clayman Institute for Gender Research, Stanford University, \& Anita Borg Institute for Women and Technology.

Sinclair, L. \& Kunda, Z. (2000). Motivated Stereotyping of Women: She's Fine if She Praised me but Incompetent if She Criticizes Me, Personality and Social Psychology Bulletin, vol.26:2, pp.1329-1342.

Stack, S. (2004). Gender, Children and Research Productivity. Research in Higher Education, vol.45:8, pp.891-920.

Stratton, T. D., Witzke, D. B., Elam, C. L. \& Cheever, T. R. (2005). Learning and Career Specialty Preferences of Medical School Applicants, Journal of Vocational Behavior, vol.67:1, pp.35-50.

Taylor, K. S., Lambert, T. W. \& Goldacre, M. J. (2001). Career Progression and Destinations, Comparing Men and Women in the NHS: Postal Questionnaire Surveys, British Medical Journal, vol.33:8, pp.1735-157.

Turner, S. L., Conkel, J. L., Starkey, M., Landgraf, R., Lapan, R. T., Siewert, J. J., Reich, A.,Trotter, M. J., Neumaier, E. R. \& Huang, J. (2008). Gender Differences in Holland Vocational Personality Types: Implications for School Counselors, Professional School Counseling, vol.11:5, pp.317-26.

Tyler, I. (2009). Assessing Canadian Medical Students' Familiarity with and Interest in Pursuing Career in Community Medicine, Canadian Journal of Public Health, vol.100:3, pp.194-8. 
Van de Gaer, E., Pustjens, H., Van Damme, J. \& De Munter, A., (2006). Tracking and the Effects of School-Related Attitudes on the Language Achievement of Boys and Girls, British Journal of Sociology of Education, vol.27:3, pp.293-309.

Weeks, J. (2000). Making Sexuality History. Cambridge: Polity Press.

Williams, M. L., Ford, L. R., Dohring, P. L., Lee, M. D. \& MacDermid, S. M. (2000). Outcomes of Reduced Load Work Arrangements at Managerial and Professional Levels: Perspectives from Multiple Stakeholders. Paper Presented at the Annual Meetings of the Academy of Management, Toronto, Ontario.

Woolf, K. (2009). The Academic Underperformance of Medical Students from Ethnic Minorities. London : University of London Press.

Xie, Y. \& Shauman, K. A. (2003). Women in Science: Career Processes and Outcomes. Cambridge, MA: Harvard University Press.

Zikriya, Rafia. (2014). Pakistan's Medical Schools: Where The Women Rule, Newspaper Dawn, April 23.

Aamir Hafeez is Ph.D Research Scholar in the Department of Education, Hazara University, Mansehra.

Prof. Dr. Syed Manzoor Hussain Shah is Chairman in the Department of Education, Hazara University, Mansehra. 